\title{
Large cell neuroendocrine carcinoma presenting with neck swelling in the submandibular gland: a case report
}

Hideto Kawaratani ${ }^{1 *}$, Tatsuhiro Tsujimoto ${ }^{1}$, Masaaki Yoshikawa ${ }^{1}$, Fumi Kawanami ${ }^{1}$, Yusaku Shirai ${ }^{1}$, Hitoshi Yoshiji ${ }^{1}$, Kousaku Morita ${ }^{2}$ and Hiroshi Fukui ${ }^{1}$

\begin{abstract}
Introduction: Large cell neuroendocrine carcinoma in the salivary glands is rare. We report a second case of large cell neuroendocrine carcinoma of the submandibular gland diagnosed at autopsy, and a review of the literature.

Case presentation: A 68-year-old Japanese man was referred to our hospital for thorough investigation of swelling on the right side of his neck. Fine-needle aspiration cytology of the cervical mass suggested poorly differentiated metastatic carcinoma. The primary tumor could not be detected by several examinations. One month after admission, he died of cancer. An autopsy was performed, and it revealed a tumor of the right submandibular gland. The histopathological diagnosis was large cell neuroendocrine carcinoma of the submandibular gland.

Conclusion: To the best of our knowledge, only eight cases of large cell neuroendocrine carcinoma in the salivary glands, including our case, have been reported. This report indicates total biopsy and immunohistochemistry are necessary for diagnosing large cell neuroendocrine carcinoma properly.
\end{abstract}

Keywords: Autopsy, Large cell neuroendocrine carcinoma, Salivary gland, Submandibular gland

\section{Introduction}

Large cell neuroendocrine carcinoma is defined as a variant form of large cell carcinoma, and is classified in the wide spectrum of primary neuroendocrine tumors together with small cell carcinoma (SCC) and atypical carcinoid tumor. Travis et al. proposed a distinctive clinicopathological entity of pulmonary neuroendocrine tumors in 1991 [1]. Large cell neuroendocrine carcinoma has poor prognosis like SCC. Although the lung is the most common location of this tumor, large cell neuroendocrine carcinomas have been found in other organs, including the thymus [2], stomach [3], gall bladder [4], uterine cervix [5], urinary bladder, and so on. In the salivary glands, neuroendocrine carcinoma is sometimes seen [6], but large cell neuroendocrine carcinoma is extremely rare, and only seven cases have been reported [7-12]. Their biological behaviors are still

\footnotetext{
* Correspondence: kawara1010@yahoo.co.jp

${ }^{1}$ Third Department of Internal Medicine, Nara Medical University, 840

Shijo-cho, Kashihara, Nara 634-8522, Japan

Full list of author information is available at the end of the article
}

unknown. Recently, we have encountered large cell neuroendocrine carcinoma of the submandibular gland that was diagnosed at autopsy, but was difficult to distinguish from metastatic tumor. Here we describe this rare case and present a review of the literature.

\section{Case presentation}

A 68-year-old Japanese man was referred to our hospital for thorough investigation of right hypochondriac pain and painless swelling on the right side of his neck. He had a past history of a transverse colon cancer operation about 18 years earlier and underwent distal gastrectomy and cholecystectomy due to duodenal ulcer 30 years earlier. He had gone to another hospital for diabetes mellitus follow up. One month earlier, he was referred to the same hospital because of right hypochondriac pain and anorexia. Plain abdominal computed tomography $(\mathrm{CT})$ scanning revealed a low density area in his liver segment 8 . At first, because of his cervical swelling, hepatic carcinoma with neck metastasis was suspected. He was admitted into an affiliated hospital for further

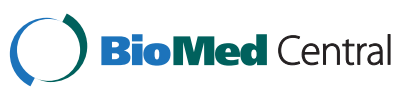




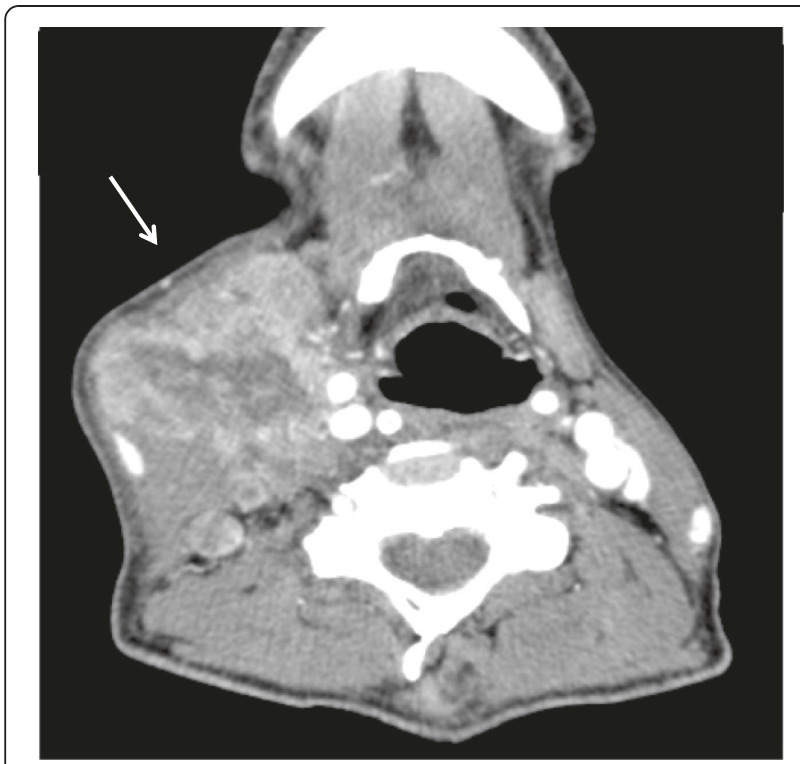

Figure 1 Computed tomography showed enlargement of lymph nodes on the right side of the neck (arrow).

examinations. Esophagogastroduodenoscopy and colonoscopy were performed, but both revealed no malignancy. Enhanced abdominal CT scanning showed no tumor in his liver and other abdominal organs. Enhanced thoracic CT scanning showed enlargement of right cervical lymph nodes (Figure 1), but no primary tumors could be detected. ${ }^{18} \mathrm{~F}$-fluorodeoxyglucose (FDG) positron emission tomography (PET) could not be taken because of the patient's poor systemic condition and there was no instrument in our hospital. Subsequently, fine-needle aspiration cytology (FNAC) of the right cervical mass was performed, and it suggested poorly differentiated carcinoma. Metastatic carcinoma was suspected, but primary organs could not be detected. For further examinations, he was transferred to our hospital after 3 weeks. He had a poor systemic condition and showed multiple metastases of the spine. Then, disseminated intravascular coagulation gradually developed. He died of cancer 5 days after his transfer to our hospital.
Because the primary carcinoma was unknown, autopsy was performed after his death. At autopsy, a tumor of about $5 \mathrm{~cm}$ was found in the right submandibular gland. No other primary malignant tumor was detected, except metastasis to the bone marrow and spine. Histological examination of the submandibular tumor revealed a solid growth formed of large polygonal atypical cells. An organoid structure, and palisading, rosette growth were seen, and the tumor had focal squamous differentiation (Figure 2). The tumor showed diffuse necrosis and many mitoses (about 40 cells/10 high-power field). It was difficult to distinguish poorly differentiated SCC, basal cell adenocarcinoma, mixed SCC, and basaloid SCC. Immunohistochemically, CD56 and synaptophysin were positive (Figure 3), whereas chromogranin A, p63, alpha smooth muscle actin, and thyroid transcription factor-1 were negative. There is no report of salivary basaloid SCC. And basal cell adenocarcinoma or mixed SCC were ruled out because of positive synaptophysin which is expressed on neuroendocrine tumors. Based on these findings, the tumor was finally diagnosed as large cell neuroendocrine carcinoma of the submandibular gland.

\section{Discussion}

Salivary gland carcinoma is a rare neoplasm accounting for $0.3 \%$ of all human cancers. The treatment for salivary gland carcinoma is mainly surgery, including primary tumor resection with or without neck lymph node dissection and adjuvant therapy. Salivary gland carcinoma is mainly diagnosed by CT or MRI and echoguided FNAC. Recently, FDG-PET has become a useful modality for detecting salivary gland carcinoma. And FDG-PET has been reported to be superior to CT and/ or MRI in detecting neck cancers [13].

Large cell neuroendocrine carcinoma is a poorly differentiated, high-grade neuroendocrine neoplasm that has several morphological and biological features between SCC and atypical carcinoid [1]. The lung is the most common location of large cell neuroendocrine carcinoma. The main features of large cell neuroendocrine carcinoma are those of neuroendocrine cancer, such as organoid nesting,

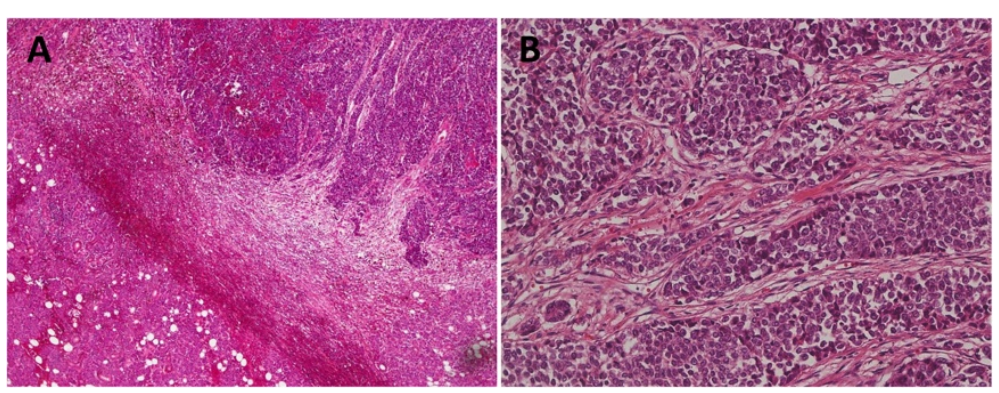

Figure 2 Hematoxylin and eosin staining showed solid growth of large polygonal atypical cells, organoid structure, palisading, and rosette growth. A: 40-fold, B: 200-fold. 

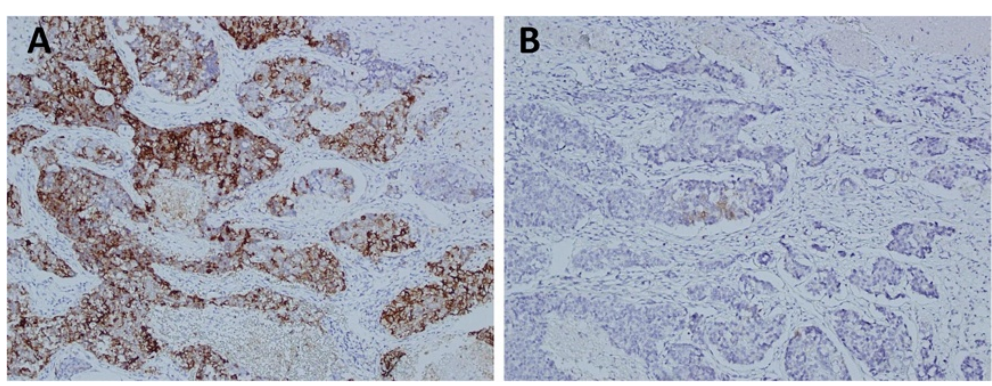

Figure 3 A: On immunohistochemistry, the tumor cells show positive for CD56. B: The tumor cells show positive for synaptophysin.

palisading, rosette trabeculae, large cells with a polygonal shape, a relatively low nuclear to cytoplasmic ratio, frequent necrosis mimicking non-SCC, and positive neuroendocrine immunohistochemical markers. To confirm the neuroendocrine features, the tumor cells were stained with antibodies to CD56, synaptophysin, and chromogranin A [14]. Recently, various immunohistochemical techniques have been performed to diagnose neuroendocrine tumors, like neural cell adhesion molecule [15].

This tumor is very rare, and hence there is no consensus on management guidelines. As large cell neuroendocrine carcinoma is sometimes mistaken for a poorly differentiated carcinoma or SCC, immunohistochemistry is important in making the diagnosis of large cell neuroendocrine carcinoma. For pulmonary large cell neuroendocrine carcinoma, surgery is the main treatment and can be complemented with postoperative radiotherapy or chemotherapy. The prognosis of pulmonary large cell neuroendocrine carcinoma is poor. The prognosis of salivary gland large cell neuroendocrine carcinoma seems to be poor, too. Early diagnosis and early treatment are desirable for improvement of the outcomes. More studies are needed to better define the therapeutic alternatives and prognostic factors of salivary gland large cell neuroendocrine carcinoma.

Our review of the medical literature in PubMed between 1975 and 2011 revealed seven cases of salivary gland large cell neuroendocrine carcinoma [7-12]. The details of all eight reported cases, including our present case, are shown in Table 1. There were five men and two women, and their mean age was 75 years (ranging from 68 to 88 years). The most commonly presenting symptom was painless swelling of the neck. The location of the tumors was: five in the parotid and two in the submandibular and none in the

Table 1 Previously reported cases of salivary gland large cell neuroendocrine carcinoma

\begin{tabular}{|c|c|c|c|c|c|c|c|c|c|c|}
\hline Reference & Age & Sex & $\begin{array}{l}\text { Past } \\
\text { history }\end{array}$ & $\begin{array}{l}\text { Presenting } \\
\text { complaints }\end{array}$ & $\begin{array}{l}\text { Size } \\
\text { of } \\
\text { tumor }\end{array}$ & Location & FNAC findings & $\begin{array}{l}\text { Immunohisto- } \\
\text { chemical } \\
\text { findings }\end{array}$ & Treatment & Outcome \\
\hline $\begin{array}{l}\text { Hui et al. } \\
{[7]}\end{array}$ & n.r. & n.r. & n.r. & n.r. & n.r. & n.r. & not performed & n.r. & n.r. & n.r. \\
\hline $\begin{array}{l}\text { Larsson } \\
\text { and } \\
\text { Donner [8] }\end{array}$ & 88 & $\mathrm{~F}$ & n.r. & $\begin{array}{l}\text { mobile mass of } \\
\text { neck }\end{array}$ & $2 \mathrm{~cm}$ & right parotid & $\begin{array}{l}\text { undifferentiated } \\
\text { carcinoma }\end{array}$ & Chr (-), Syn (+) & Op and $R x$ & $\begin{array}{l}3 \text { years disease } \\
\text { free }\end{array}$ \\
\hline $\begin{array}{l}\text { Nagao } \\
\text { et al. [9] }\end{array}$ & 72 & $\mathrm{~F}$ & n.r. & $\begin{array}{l}\text { enlargement of } \\
\text { neck }\end{array}$ & $7 \mathrm{~cm}$ & right parotid & $\begin{array}{l}\text { large cell } \\
\text { undifferentiated } \\
\text { carcinoma }\end{array}$ & Chr $(-)$, Syn $(+)$ & $\begin{array}{l}\text { Cx and Op } \\
\text { and } R x\end{array}$ & $\begin{array}{l}\text { died } 5 \text { months } \\
\text { after operation }\end{array}$ \\
\hline $\begin{array}{l}\text { Nagao } \\
\text { et al. [9]. }\end{array}$ & 73 & $M$ & n.r. & $\begin{array}{l}\text { enlargement of } \\
\text { neck }\end{array}$ & $3.3 \mathrm{~cm}$ & right parotid & not performed & Chr $(+), \operatorname{Syn}(-)$ & Op and $R x$ & $\begin{array}{l}\text { died } 4 \text { years after } \\
\text { operation }\end{array}$ \\
\hline $\begin{array}{l}\text { Casas et al. } \\
{[10]}\end{array}$ & 74 & $M$ & n.r. & $\begin{array}{l}\text { enlargement of } \\
\text { neck }\end{array}$ & $9 \mathrm{~cm}$ & left parotid & $\begin{array}{l}\text { large cell } \\
\text { undifferentiated } \\
\text { carcinoma }\end{array}$ & Chr $(+)$, Syn $(+)$ & $O p$ and $R x$ & $\begin{array}{l}8 \text { months disease } \\
\text { free }\end{array}$ \\
\hline $\begin{array}{l}\text { Ueo et al. } \\
{[11]}\end{array}$ & 72 & $M$ & $\begin{array}{l}\text { gastric } \\
\text { cancer }\end{array}$ & $\begin{array}{l}\text { enlargement of } \\
\text { neck }\end{array}$ & $4.5 \mathrm{~cm}$ & right parotid & not performed & Chr $(+)$, Syn $(+)$ & Op and $R x$ & $\begin{array}{l}\text { died } 8 \text { months } \\
\text { after operation }\end{array}$ \\
\hline $\begin{array}{l}\text { Sowerby } \\
\text { et al. [12] }\end{array}$ & 81 & $M$ & none & facial paralysis & $6 \mathrm{~cm}$ & $\begin{array}{l}\text { left } \\
\text { submandibular }\end{array}$ & $\begin{array}{l}\text { atypical } \\
\text { lymphoid } \\
\text { proliferation }\end{array}$ & Chr $(-)$, Syn $(+)$ & Cx and Rx & $\begin{array}{l}27 \text { months disease } \\
\text { free }\end{array}$ \\
\hline This report & 68 & $M$ & $\begin{array}{l}\text { DM, } \\
\text { colon } \\
\text { cancer }\end{array}$ & $\begin{array}{l}\text { abdominal pain } \\
\text { enlargement of } \\
\text { neck }\end{array}$ & $5 \mathrm{~cm}$ & $\begin{array}{l}\text { right } \\
\text { submandibular }\end{array}$ & $\begin{array}{l}\text { poorly } \\
\text { differentiated } \\
\text { carcinoma }\end{array}$ & Chr $(-)$, Syn $(+)$ & none & $\begin{array}{l}\text { died } 1 \text { month } \\
\text { after symptom } \\
\text { appeared }\end{array}$ \\
\hline
\end{tabular}

Chr = chromogranin; Cx = chemotherapy; DM = diabetes mellitus; FNAC = fine-needle aspiration cytology; .r. = not recorded; Op = operation; Rx = radiation; Syn = synaptophysin. 
sublingual gland. Moreover, five were on the right side and two were on the left side. FNAC was performed in five cases. The pathological findings of FNAC were undifferentiated or poorly differentiated carcinoma. The size varied greatly from $2 \mathrm{~cm}$ to $9 \mathrm{~cm}$. Synaptophysin was positive in six cases, and chromogranin A was positive in three cases. Five cases underwent surgery and radiation therapy postoperatively. One case underwent a combination of chemotherapy and radiation therapy. The outcome varied; three cases died after surgery (5 months, 8 months, and 4 years), whereas three cases had a good outcome with improvement of tumor and free from tumor recurrence after treatment (8 months, 27 months, and 3 years). In our case, the patient died of cancer, and the autopsy revealed large cell neuroendocrine carcinoma of the submandibular gland.

\section{Conclusion}

In this report we presented a rare case of large cell neuroendocrine carcinoma of the submandibular gland. Diagnosis based on FNAC findings was difficult because of the small samples of tissue. If a patient presents with enlargement of the neck, then total biopsy or operation and immunohistochemistry are needed to diagnose salivary gland tumor. Since salivary gland large cell neuroendocrine carcinoma is rare and has a poor prognosis, similar to the pulmonary large cell neuroendocrine carcinoma, early diagnosis is necessary to improve the prognosis of this disease.

\section{Consent}

Written informed consent was obtained from the patient's family for publication of this case report and accompanying images. A copy of the written consent is available for review by the Editor-in-Chief of this journal.

\section{Competing interests}

All authors declare that they have no competing interest.

\author{
Authors' contributions \\ HK analyzed and interpreted the patient data. MY and FK have been \\ involved in direct patient care at different time points. YS did the literature \\ search. KM performed the pathological examination of the tumor. $T \mathrm{~T}$ and $\mathrm{HY}$ \\ were major contributors in writing the manuscript. HF did the final draft \\ proof reading and approval. All authors read and approved the final \\ manuscript.
}

\section{Acknowledgements}

We thank Prof. Toshitaka Nagao, Department of Surgical Pathology, Tokyo

Medical University Hospital for his advice on the pathological diagnosis.

\section{Author details}

${ }^{1}$ Third Department of Internal Medicine, Nara Medical University, 840 Shijo-cho, Kashihara, Nara 634-8522, Japan. ${ }^{2}$ Department of Diagnostic Pathology, Nara Medical University, 840 Shijo-cho, Kashihara, Nara 634-8522, Japan.

Received: 14 August 2012 Accepted: 12 February 2013

Published: 19 March 2013

\section{References}

1. Travis WD, Linnoila Rl, Tsokos MG, Hitchcock CL, Cutler GB Jr, Nieman L, Chrousos G, Pass H, Doppman J: Neuroendocrine tumors of the lung with proposed criteria for large-cell neuroendocrine carcinoma: an ultrastructural, immunohistochemical, and flow cytometric study of 35 cases. Am J Surg Pathol 1991, 15:529-553.

2. Chetty R, Batitang S, Govender D: Large cell neuroendocrine carcinoma of the thymus. Histopathology 1997, 31:274-276.

3. Matsui K, Jin XM, Kitagawa M, Miwa A: Clinicopathologic features of neuroendocrine carcinomas of the stomach: appraisal of small cell and large cell variants. Arch Pathol Lab Med 1998, 122:1010-1017.

4. Lin D, Suwantarat N, Kwee S, Miyashiro M: Cushing's syndrome caused by an ACTH-producing large cell neuroendocrine carcinoma of the gallbladder. World J Gastrointest Oncol 2010, 2:56-58.

5. Gilks CB, Young RH, Gersell DJ, Clement PB: Large cell neuroendocrine [corrected] carcinoma of the uterine cervix: a clinicopathologic study of 12 cases. Am J Surg Pathol 1997, 21:905-914.

6. Vandist V, Deridder F, Waelput W, Parizel PM, Van de Heyning P, Van Laer C: A neuroendocrine tumour of the sphenoid sinus and nasopharynx: a case report. B-ENT 2010, 6:147-151.

7. Hui KK, Luna MA, Batsakis JG, Ordonez NG, Weber R: Undifferentiated carcinomas of the major salivary glands. Oral Surg Oral Med Oral Pathol 1990, 69:76-83.

8. Larsson $L G$, Donner LR: Large cell neuroendocrine carcinoma of the parotid gland: fine needle aspiration, and light microscopic and ultrastructural study. Acta Cytol 1990, 43:534-536.

9. Nagao T, Sugano I, Ishida Y, Tajima Y, Munakata S, Asoh A, Yamazaki K, Muto $\mathrm{H}$, Konno A, Kondo $Y$, Nagao K: Primary large-cell neuroendocrine carcinoma of the parotid gland: immunohistochemical and molecular analysis of two cases. Mod Pathol 2000, 13:554-561.

10. Casas P, Bernáldez R, Patrón M, López-Ferrer P, García-Cabezas MA: Large cell neuroendocrine carcinoma of the parotid gland: case report and literature review. Auris Nasus Larynx 2005, 32:89-93.

11. Ueo T, Kaku N, Kashima K, Daa T, Kondo Y, Yoshida K, Suzuki M, Yokoyama S: Carcinosarcoma of the parotid gland: an unusual case with large-cell neuroendocrine carcinoma and rhabdomyosarcoma. APMIS 2005, 113:456-464.

12. Sowerby $\sqcup$, Matthews TW, Khalil M, Lau H: Primary large cell neuroendocrine carcinoma of the submandibular gland: unique presentation and surprising treatment response. J Otolaryngol 2007, 36:E65-E69.

13. Kim SY, Kim JS, Doo H, Lee H, Lee JH, Cho KJ, Choi SH, Nam SY, Roh JL: Combined $\left[{ }^{18} \mathrm{~F}\right]$ fluorodeoxyglucose positron emission tomography and computed tomography for detecting contralateral neck metastases in patients with head and neck squamous cell carcinoma. Oral Oncol 2011, 47:376-380

14. Loy TS, Darkow GV, Quesenberry JT: Immunostaining in the diagnosis of pulmonary neuroendocrine carcinomas. An immunohistochemical study with ultrastructural correlations. Am J Surg Pathol 1995, 19:173-182.

15. Kusafuka K, Asano R, Kamijo T, lida Y, Onitsuka T, Kameya T, Nakajima T: Large cell neuroendocrine carcinoma of the tongue base: case report of an unusual location with immunohistochemical analysis. Int J Oral Maxillofac Surg 2009, 38:296-299.

\section{doi:10.1186/1752-1947-7-81}

Cite this article as: Kawaratani et al.: Large cell neuroendocrine carcinoma presenting with neck swelling in the submandibular gland: a case report. Journal of Medical Case Reports 2013 7:81. 